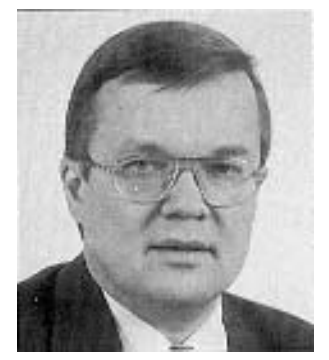

Tapio Varmola

\title{
Markkinoiden mahdollisuudet koulutuksessa
}

\begin{abstract}
"Tutkimuksessani olen pyrkinyt selvittämään talouden ja hallinnon markkinakäsitteiden sovellettavuutta koulutuksen eri asteille ja koulutuksen eri tasoille: sen kysyntään, tarjontaan ja ohjaukseen. Kun yhteenvedossa sivutaan aikuiskoulutuksen ohella myös perusasteen ja korkea-asteen koulutusta, muodostuu näkökulma varsin laajaksi."
\end{abstract}

\section{ETYMOLOGIA JA MIELIKUVA}

Sana markkinat tarkoittaa etymylogisesti Spaikkaa, jonne ihmiset kokoontuvat myymään ja ostamaan tavaraa. Useimpien mieleen se tuonee kaupungin torin, johon markkinaväki on kokoontunut myyntikojujen ympärille.

Nuori kaksikymmenvuotias arkkitehtiopiskelija muistelee lapsuutensa markkinoita koulukaupungissaan näin:

"Olen käynyt koulua eräässä maamme pikkukaupungissa ja siellä päässyt myös ensimmäiselle luokalle elämän koulussa. Edelleenkin olen sitä mieltä, että pikkukaupunki on ihanin kaikista maailman sekalaisista asuinybdyskunnista, ainoa paikka missä elämä pystyy tarjoamaan edes vähän enemmän väriä ja vilinää katselunbaluiselle nuorukaiselle.

Erityisen byvin minä muistan syksyn. Kaikki oli maaltamunton jälkeen uutta, jopa koulu, vanha suomalainen lyseo. Ja sitten sesonki buipentui syysmarkkinoibin. Sinne minä halusin päästä. Synnynnäisellä jätkänluonteellani oitis tajusin syysmarkkinoiden eldoradomaisuuden."

Ja edelleen:

"Mutta markeinoibin palatakseni, te helsinkiläiset ette ymmärrä sitä ilmapiiriä joka ympäröi syysmarkkinoita pikkukaupungissa. Siellä oli kaikekea mabdollista ybdellä kertaa. Ylös noustiin aamulla varbain ja elämä aloitettiin noin markan suuruisella käsikassalla. Ensin mentiin torille, juotiin kojuissa kabvia sokeroitujen lättyjen kera ja käveltiin sitten arvokkaasti hevoshuijareiden joukossa pureskellen buonolaatuisinta makkaraa, ainoaa vapaan kansalaisen arvon mukaista ruokaa." (Schildt, 1982, 36).

Lainaukset ovat Alvar Aallon pakinasta, jonka hän on laatinut koulukaupungistaan Jyväskylästä vuosisadan alusta. Siinä hän kuvaa pienen pojan silmin pikkukaupungin markkinoita, sen houkutuksia ja vaaroja. Sellaisilla pikkukaupunkimarkkinoilla moni suomalainen 
nuori on saanut oppikouluvuosinaan ensikokemuksia markkinatalouden toiminnasta.

Talouden ja hallinnon kielissä markkinoista on muodostunut viime vuosina poikkeuksellisen voimakas käsite. Syy on ensi näkemältä hyvin yksinkertainen: talouden markkinatalousmallista on muodostunut yhteiskuntaideologisesti ikään kuin ainoa vaihtoehtoehto sen jälkeen kun sosialistiset suunnitelmataloudet ovat yksi toisensa jälkeen kokeneet poliittisen haaksirikon. Eurooppa ja laajemminkin pääosa pohjoista pallonpuoliskoa on täynnä maita, jotka kutsuvat itseään markkinatalousmaiksi.

$\mathrm{M}$ arkkinakäsitteen voimakkuus liittyy siihen, että yhteiskuntatieteellisessä ajattelussa se kokoaa hyvinvoinnin vaihtoehdot toimivaksi poliittiseksi ajattelutavaksi, joka pohjaa yksilön etiikalle(missä tärkeää on yksilöllisyys, valinta, vapaus), tehokkuuden periaatteelle (missä tärkeää on kilpailu sekä tuotteiden ja palveluiden hinta) sekä arvioimisen ja kehittämisen mekanismeille. Samalla markkinoiden kieli toimii älyllisenä välineenä, jonka avulla maailmasta voidaan tehdä ajateltava ja ymmärrettävä toiminnan kohde. Markkinoiden kieli ei toimi maailman selityksenä, mutta konkreettisuudessaan se antaa kenelle tahansa meistä mahdollisuuden omakohtaisesti pohtia maailman muuttumista. (Rose, 1995)

Talouden ja hallinnon markkinakäsitteitä on sovellettu ja niitä voidaan soveltaa jonkin hyvinvointipolitiikan lohkon toiminnan kuvaukseen. Väitöskirjatutkimuksessani on kyse markkinakäsitteiden soveltamisesta koulutuksen eri asteille ja tasoille.

\section{KANSAINVÄLINEN JA KANSALLINEN LINJA}

K oulutuksen alueella markkinakäsitteiden käytön voimistuminen on kansainvälinen ilmiö, joka on hallinnut OECD-maiden kehitystä 1980-luvulta lähtien. Ruotsalainen Holger Daun (1993) kuvaa tätä kehitystä niin, että kahdeksankymmenluvun koulu-uudistuksia on hallinnut pyrkimys koulutuksen rakennekehi- tykseen, jota voidaan ohjata kahdesta suunnasta: joko poliittiselta kentältä tai markkinoilta käsin. Markkinaohjauksen puolestapuhujat katsovat, että poliitikot voivat kyllä päättää koulutusuudistusten suurista linjoista, mutta niiden toteuttaminen ja arviointi tulee jäädä koulutuksen sisälle, siis poliittisen kentän ulottumattomiin.

Markkina-ajattelu saa kaksi varsinaista päätulkintaa. Ensinnäkin voidaan ajatella markkinoiden toimintaa koulutusjärjestelmän sisällä analogiana. Koulujen ja oppilaitosten tulisi toimia ikään kuin ne toimisivat tarjonnan markkinoilla. Tällaisessa mallissa korostuu opiskelijan tai koulutuksen ostajan valinnan mahdollisuus.

Toinen tulkinta menee pitemmälle markkinaajattelun soveltamisessa. Ajatellaan, että koulujen tulee toimia kuin yritysten: niitä tulee johtaa kuin yrityksiä ja niiden tuotteita - opetusta - tulee myydä ja ostaa kuten palveluksia yleensä. Tämän ajattelun puolestapuhujat painottavat myös koulujen privatisointia, siis niiden omistussuhteiden muutosta julkisista yksityisiksi.

Daunin yhteenveto koskee OECD-maiden kehitystä 1990-luvun alussa ja se liittyy Ruotsissa käytyyn vilkkaaseen keskusteluun itsenäisistä kouluista eli oikeammin sanottuna yksityiskouluista. Yhteenveto osoittaa, että markkina-analogiaa oli tuolloin vahvistettu useissa OECDmaissa, muun muassa Yhdysvalloissa, koko IsoBritanniassa, Hollannissa, Australiassa, Uudessa Seelannissa ja Japanissa, kun taas Saksa, Ranska ja Kanada näyttivät pidättäytyneen merkittävistä markkina-analogisista toimista.

Miksi pohtia lähinnä peruskoulutukseen liittyviä kansainvälisiä virtauksia tutkimuksessa, jonka empiirinen osa käsittelee ammatillista aikuiskoulutusta? Näkökulman laajentaminen on mielestäni perusteltua monestakin syystä.

Koulutus on Suomessa kaikilla koulutusasteilla julkinen hyödyke. Peruskoulut, lukiot, ammatilliset oppilaitokset, ammattikorkeakoulut ja yliopistot ovat muutamaa poikkeusta lukuun- 
ottamatta julkisesti omistettuja ja niiden toiminta on verovaroin rahoitettua. Kansalaisina rahoitamme niiden toiminnan luovuttamalla osan tuloistamme veroina koulutushyödykkeiden tuottamista varten. Asian kääntöpuoli on se, että opetus eri asteen oppilaitoksissa on ilmaista ja opiskelijoiden elämää - matkoja, oppikirjoja, asumista - tuetaan valtion ja kuntien toimesta.

Kansalaisten tuki esimerkiksi kunnallisille koulupalveluille näyttää erilaisten tutkimusten ja selvitysten valossa rikkumattomalta. Silti voi kysyä, olisivatko suomalaiset nyt valmiita rahoittamaan yhtä laajan julkisen kouluverkon rakentamisen, jos voisimme palata ajassa taaksepäin neljännesvuosisadan verran. Vaihtoehdon voi esittää näinkin: valittaisiinko mieluummin korkea veroaste ja ilmainen koulutus vai matalampi veroaste ja koulumaksut?

\section{AMMATILLISEN AIKUISKOULUTUKSEN MARKKINASUUNTAUTUNEISUUDESTA}

\begin{abstract}
Amatillisesta aikuiskoulutuksesta on kymmenen viime vuoden aikana muodostunut markkinasuuntautuneen koulutuspolitiikan koekenttä. Muutos on ollut merkittävä, koska koulutuksen ohjaustapaa on pyritty muuttamaan sen kysyntään perustuvaksi. Oppilaitosten välinen kilpailu on sallittu ja sitä on jopa kannustettu. Koulutuksen tarjonnan monopolit on yleensä purettu.
\end{abstract}

Aikuiskoulutuksen tarjonnan markkinat ovat kasvaneet, mutta aitoa markkinatilannetta, saati puolittaismarkkinoidenkaan tilannetta ei oikeastaan ole saavutettu. Kaksi markkina-ajattelun osatekijää toimii ammatillisessa aikuiskoulutuksessa hyvin puutteellisesti: kuluttajan valinta ja hintamekanismi.

$\int$ os koulutuksessa halutaan edistää markkinoiden toimintaa, on vahvistettava koulutuksen tarjonnan ja kysynnän välitöntä vuoropuhelua. Oppilas, hänen vanhempansa, opiskelija tai koulutusta tarvitseva yritys on kuluttajan asemassa, jonka on voitava valita eri vaihtoehdoista ja vertailla niitä keskenään. Toimiessamme markkinoilla kuluttajana vertailemme tavallisesti tuotteen hintaa ja laatua ja teemme tuotteen hankintapäätöksiä näitä tekijöitä painottaen.

Suomessa ja Pohjoismaissa koulutuksen hinStaelementti on kuluttajan kannalta varsin etäinen. Opetus on maksutonta ja opintososiaaliset kustannukset ovat subventoidut. Kun kouluttautuminen näyttää tuottavan yksilöllistä hyötyä ja kun siihen osallistumiseen on kaikilla yhtäläiset mahdollisuudet, ei kuluttajan tarvitse varsinaisesti pohdiskella eri koulutustuotteiden laadullisia eroja.

Silti on mahdollista tehdä ajatuskoe, voitaisiinko ammatillisessa aikuiskoulutuksessa ajatella asia toisin: vahvistaa selvästi aikuisten omaa valinnanvapautta koulutukseen osallistumiseen tai sen ulkopuolelle jäämiseen, tuoda koulutukseen kuluttajalle näkyvä ja hänen kukkarossaan tuntuva hinta ja samalla kehittää koulutuksen rahoitukseen jonkinlainen uusi vakuutusjärjestelmä, joka perustuisi kansalaisten ja yritysten yhteiseen rahoitukseen. Muussa tapauksessa jäämme julkisesti hallinnoitujen markkinoiden tilaan, jossa päätöksenteko on kyllä alueellisesti hajautettu niin työvoimapoliittisessa koulutuksessa kuin opetushallinnon aikuiskoulutuksessa, mutta jossa muutama virkamies käyttää tilaaja-tuottajamallin mukaisesti asiantuntijan valtaa satojen aikuiskoulutusmiljoonien suuntaamisessa.

Suomen koulutusjärjestelmä on tuskin selvinSnyt rahoituskriisistään, vaikka valtion taloudellinen tila onkin nyt vakaampi kuin muutama vuosi sitten. Julkisten palvelujärjestelmien rahoituksessa selvä kehityssuunta on vaihtoehtojen luominen ja samalla kuluttajan omavastuisen rahoitusosuuden lisääminen. Koulutuspolitiikassa tätä keskustelua on pidetty veran alla. Koulutuspoliittisen konsensuksen vaalimisesta näyttää muodostuneen koulutuspoliittiselle eliitille sellainen uskonkappale, että keskustelu esimerkiksi koulumaksuista tai yksityisistä kouluista siirretään sivuun.

Tutkimuksessani on pyritty selvittämään talou- 
den ja hallinnon markkinakäsitteiden sovellettavuutta koulutuksen eri asteille ja koulutuksen eri tasoille: sen kysyntään, tarjontaan ja ohjaukseen. Kun yhteenvedossa sivutaan aikuiskoulutuksen ohella myös perusasteen ja korkeaasteen koulutusta, muodostuu näkökulma varsin laajaksi. Ymmärtääkseni aikuiskoulutuksen ja nuorten koulutuksen ero pelkistyy lopulta kasvatusfilosofiseen peruskysymykseen: onko meillä vanhempina oikeus puuttua lasten ja nuorten koulutukseen enemmän kuin aikuisina toisten aikuisten koulutusvalintoihin. Oma vastaukseni on selkeästi myönteinen: aikuiset ihmiset vanhempina ja opettajina voivat tietää ja heidän tuleekin tietää enemmän kuin nuorten siitä, mikä nuorten opetuksessa ja kasvatuksessa on tärkeää. He vastaavat nuorten opetuksen järjestämisestä myös äänestäjinä ja poliittisina päätöksentekijöinä.

Aikuiskoulutuksessa tilanne on toisin: tasavertaiset aikuiset päättävät ja vastaavat itse koulutuksestaan. Tuskinpa edes aikuiskasvatuksen professori voi tietää paremmin kuin naapurinsa, onko naapurin elämälle hyväksi osallistuminen aikuiskoulutukseen vai tämän omaehtoinen jättäytyminen koulutusmarkkinoiden ulkopuolelle.

$\mathrm{K}$ oulutuspolitiikassa on edelleen mahdollista tehdä tietoisia, poliittisia valintoja markkinamekanismin vahvistamisesta jollakin koulutusjärjestelmän osa-alueella. Tällöin olisi tietenkin otettava huomioon koulutuspolitiikan toteutuksen todellisuus: markkinamekanismin soveltaminen edellyttää paljon tarjontaa ja paljon kysyntää. Voi kysyä - niin kuin tutkimuksessani olen pyrkinyt tekemään - ratkeavatko aikuiskoulutuksen ja yleisemmin koulutuksen markkinoiden kehittymismahdollisuudet käytännössä Suomen erikokoisissa "pikkukaupungeissa".

\section{Iatreat}

DAUN, H. (1993) Omstrukturering av skolsystemen. Desentralisering, valfribet och privatisering. En internationell översikt. Skolverket. Stockholm.

ROSE, N. (1995) Eriarvoisuus ja valta byvinvointivaltion jälkeen. Teoksessa Eräsaari, R. \& Rahkonen, K. (toim.) Hyvinvointivaltion tragedia. Keskustelua eurooppalaisesta hyvinvointivaltiosta. 19-56. Gaudeamus:Tampere.

SCHILDT, G. (1982) Valkoinen pöytä. Alvar Aallon nuoruus ja taiteelliset perusideat. Otava: Helsinki.

Tapio Varmola puolusti väitöskirjaansa Markkinasuuntautuneen koulutuksen aikakauteen? Esimerkkejä ja tulkintoja ammatillisesta aikuiskoulutuksesta. Acta Universitatis Tamperensis. SerA vol 524 19.12.1996Tampereen yliopiston kasvałustieteellisen tiedekunnan väitöstilaisuudessa. Oheinen Tapio Varmolan teksti on hänen Lectio praecursoriansa.

\section{Uttatutkimsta ja kirjillisuta}

BLATNER ADAM (1997) Toiminnalliset menetelmät terapiassa ja koulutuksessa. psykodraaman ja sosiodraaman tekniikat käytäntöön sovellettuna. Suomen Morenoinstituutin julkaisusarja nro 2. Naantali.

HELAKORPI S., JUUTI P. \& NIEMI H. (1996) Tiimiorganisoitu koulu. Opetus 2000. WSOY.

JALKANEN RAIMO (1997) Kebittämisrybmät muntoksen apuvälineenä. Helsingin Pubelin Oy:n koulutusprojektia koskeva tapaustutkimus. Helsingin yliopiston kasvatustieteen laitoksen tutkimuksia 154.

LAMBERG PIRJO \& ENGESTRÖM YRJÖ (1996) Kehittävä työntutkimus ammatillisissa oppilaitoksissa. Helsingin yliopiston kasvatustieteen laitoksen tutkimuksia 150.

LONKA KIRSTI (1997). Explorations of Constructive Processes in Student Learning. Department of Psychology, University of Helsinki. 